\title{
Kolumbus na Slovensku alebo O vlastnom zvuku mesta Portrét Bratislavy z pera Leopolda Wolfganga Rochowanského Jozef Tancer
}

\author{
TANCER, J.: Columbus in Slovakia, or On the City's Specific Tone. \\ Leopold Wolfgang Rochowanski's Portrayal of Bratislava \\ SLOVENSKÁ LITERATÚRA, vol. 68, 2021, no. 3, pp. 263-275 \\ DOI: https://doi.org/10.31577/slovlit.2021.68.3.6 \\ ORCID ID: 0000-0001-6199-7594
}

Key words: sensuous geographies, flaneur, multi-sensorial image of the city, urban text

The article analyses the image of Bratislava in the 1936 ethnographic-literary travelogue Columbus in der Slowakei [Columbus in Slovakia] by the Austrian author Leopold Wolfgang Rochowanski (1888 - 1961). Drawing on Paul Rodaway's sensuous geographies, the article takes a look at how Rochowanski connects the flaneur's view of the city with sensual perception, especially taste, sound and vision and constructs the "city's specific tone" - a unique flavour of Bratislava. Flaneur's view determines both the elements from which the image of the city is composed (cafés, wine bars, restaurants) and the fragmentary narrative techniques that combine anecdotes, legends, stories and musings of the narrator with historical-ethnographic discourse. Rochowanski accentuates cultural and linguistic heterogeneity of the place and in doing so semantically opens Bratislava's urban text. As the result of period political context, however, he also ignores or marginalises some of the semantic layers of the city (portrayal of Jews) and in effect reduces the urban text. Rochowanski portrays Bratislava as a space of imagination coded in a complex way. From the point of view of perception, this prevents the separation of material and non-material (imaginary) layers of the urban palimpsest.

Klúčové slová: geografie zmyslov, flanér, multisenzorický obraz mesta, mestský text 

Slovensku je názov pozoruhodného bibliofilského cestopisu od rakúskeho autora Leopolda Wolfganga Rochowanského z roku $1936 .{ }^{1} \mathrm{~V}$ tejto štúdii sa sústredím na otázku, aké obsahové prvky autor používa na zobrazenie Bratislavy a akým štýlom rozprávač opisuje mesto. Budem si všímat' predovšetkým tie momenty, ktoré korešpondujú s modernými antropologickými metódami výskumu urbánneho priestoru, pri ktorých sa dostáva do popredia moment percepcie mesta a fenomén takzvanej urbánnej imaginácie (urban imaginary).

Môj prístup vychádza z otázky, ktorú si kladiem už dlhšie: Chceme sa pri výskume literárnych textov venovaných Bratislave dozvediet' niečo viac o meste? Niečo, čo básnici a prozaici zachytili a pochopili citlivejšie, jasnozrivejšie a hlbšie než geografi, sociológovia či historici? Alebo nás viac než mesto zaujímajú texty o meste ako špecifický žáner? Dajú sa vôbec tieto dve otázky od seba oddelit'? Je lepšie vychádzat' pri analýzach literárnych textov z odlišnosti alebo analógie mesta a textu, ktorá je typická pre moderné kultúrnovedné, ako aj antropologické uvažovanie o meste (Wietschorke 2013: 202-221)? Pokial' sa pokúšame o istú koherentnost' a konzekventnost' argumentácie, majú odpovede na tieto otázky zásadný vplyv na literárnovednú reflexiu vztahu literatúry a reality, minimálne $\mathrm{v}$ rámci cestopisného žánru.

\section{Úvod: mesto a text}

Mesto a literatúra k sebe patria od počiatku, takpovediac ab urbe condita alebo a primis litteris scriptis. Medzi mestom ako znakovým univerzom materializovaným v podobe budov, pamätníkov, ulíc, križovatiek, mostov, ale aj jeho obyvatel'ov, fauny a flóry, tvoriacich napospol takzvaný primárny mestský text, a reprezentáciou mesta v literatúre, vo filme či vo fotografii dochádza k neustálemu vzájomnému ovplyvňovaniu (Schenk 2007: 48). Umelecké a dokumentárne podoby mesta sú pritom súčastou jeho širokej kultúrnej textúry. Ak vnímame mesto ako materiálnu a mentálnu kultúrnu figuráciu, teda previazanost', tak v dotyku s literatúrou sa táto figurácia zároveň obohacuje o špecifické žánrové pravidlá a naratívne postupy. Mesto sa stáva $\mathrm{v}$ tom-ktorom médiu $\mathrm{v}$ súlade $\mathrm{s}$ jeho pravidlami takpovediac „textom na druhú“.

Dotyk s textom, napríklad cestopisom, môže mat' na kultúrnu textúru mesta dvojaký efekt. Môže znásobit jej polyfóniu a napríklad prostredníctvom intertextuálnych vztahov rozšírit' polia referentov či rozkryt' vrstvenie mestského palimpsestu. Alebo ju naopak môže zúžit' a vymedzit'. Prostredníctvom ideologickej inštrumentácie selektívne vybraných obsahov môže text vytýčit jasné a nepriepustné významové hranice a premenit členitý palimpsest na jednoliatu zrkadlovú plochu danej doby. Mechanizmy sémantického otvorenia i zatvorenia, ako ich nazýva Jens Wietschorke (Wietschorke 2013: 206), sa pritom môžu v rámci jedného textu uplatnit'aj vedla seba, čo je aj prípad cestopisu L. W. Rochowanského.

1 Prvá recenzia na publikáciu vyšla v Bratislave už 23. novembra 1935. Spomína sa v nej, že knihu už vidno vo výklade kníhkupectiev (P. V. 1935). Koncom roka 1935 ju recenzovali aj vo Viedni, recenzia bola uverejnená v novinách Der Tag pod autorskou značkou (N. N. 1935). 
Rakúsky novinár, knižný vydavatel', výtvarník, teoretik tanca a moderného výtvarného umenia, autor divadelných hier, básní, próz, operných libriet a pantomím L. W. Rochowanski (1888 - 1961) je dnes medzi germanistami a kunsthistorikmi možno ešte o čosi neznámejší, ako bola v medzivojnovom období krajina, ktorej venoval svoj cestopis. Stručné informácie o cestopise v kontexte Rochowanského kontaktov so slovenskými umelcami a architektmi publikovala germanistka Klára Prešnajderová (Prešnajderová 2019: 39-43). Podrobnejšie cestopis opísala kunsthistorička Julia Secklehner, no ked'že jej text koncipovaný ako internetový blog nevychádza z archívnych prameňov a nereflektuje vznik, funkciu ani recepciu diela, je v podstate viac-menej len obsahovou anotáciou, kultivovane zasadenou do širšieho dobového kontextu (Secklehner 2020).

Prv než sa dostanem k Rochowanského obrazu Bratislavy, rád by som predstavil jeho cestopis ako celok, aby som sa neprehrešil voči princípu hermeneutického kruhu. Hoci opis Bratislavy tvorí samostatnú a najrozsiahlejšiu kapitolu celej knihy, jeho význam vynikne až v súhre s ostatnými kapitolami. Tento šest'stostranový cestopis je súčast'ou takzvaného odklínajúceho diskurzu, v rámci ktorého novovzniknuté Československo upevňovalo svoju symbolickú moc na území bývalého Horného Uhorska, a to nielen symbolicky, za pomoci médií, kultúry a vzdelávania, ale tiež ekonomicky, zoštátnením „cudzieho“ majetku (Tancer 2013: 142-147). Lojalita voči Československej republike u Rochowanského neprekvapuje. Je s ňou spätý privátne (čast' jeho rodiny žije v československej časti Sliezska, odkial' autor pochádza), ako aj profesionálne, vd'aka kontaktom $\mathrm{s}$ československými umelcami a vedcami. ${ }^{2}$ Kniha ešte pred samotným textom vzdáva prostredníctvom úvodných fotografií hold zakladatel'om štátu, Masarykovi, Štefánikovi a Benešovi, ako aj Jozefovi Országhovi, úradujúcemu slovenskému krajinskému prezidentovi. O lojalite teda niet pochýb. Otázkou je, či pramení aj z komerčného kalkulu. Dielo totiž vzniklo na objednávku československých úradov za účelom propagácie turizmu ${ }^{3}$ a môžeme ho považovat' za pilotný projekt v rámci série cestopisov, ktorými Rochowanski plánoval približit' nemeckému publiku krajiny strednej a východnej Európy. Chystal knihu o Pol'sku, a to ešte pred zrealizovaním slovenského cestopisu, ${ }^{4}$ a tiež o Bulharsku. ${ }^{5}$ Po vydaní publikácie

2 Aj napriek svojim rodinným a profesionálnym kontaktom $\mathrm{L}$. W. Rochowanski češtinu neovládal a pri literatúre bol odkázaný na nemecké preklady. Pozri jeho list Josefovi Vydrovi zo 4. februára 1955, v ktorom sa st'ažuje, že nemôže čítat' Vydrove články v časopise Tvar, pretože nemá poruke prekladatela. Pozostalost' L. W. Rochowanského vo viedenskej Wienbibibliothek im Rathaus, Oddelenie rukopisov, ZPH 347, kartón číslo 3, spis Korrespondenzen mit Einzelpersonen. Vydra, Frida und Josef. V nasledujúcom texte uvádzam už len signatúru pozostalosti, kartón a spis.

3 List Československého vyslanectva vo Viedni z 22. marca 1934, v ktorom vyslanectvo odporúča podporit' Rochowanského ,všem čs. museím a archivům při jeho pracích konaných pro vydání jeho knihy o Slovensku“. Pozri tiež d'alší list vyslanectva z 18. septembra 1934 adresovaný obecným úradom na Slovensku, v ktorom sa explicitne uvádza, že L. W. Rochowanski pracuje na „objemnom díle o Slovensku, určeném cizinecké propagande“. Vyslanectvo žiada v liste úrady o súčinnost' pri získavaní obrazového materiálu pre knihu. ZPH 347, kartón číslo 7, spis Reisebücher über Wien, Polen und die Tschechoslowakei.

4 L. W. Rochowanski v liste pol'skému vyslancovi vo Viedni z 2. februára 1934. ZPH 347, kartón číslo 7, spis Reisebücher über Wien, Polen und die Tschechoslowakei.

5 Ljubeň Božkov, pracujúci pravdepodobne v diplomatických službách, d'akuje 4. februára 1936 Rochowanskému za zaslanie knihy Kolumbus na Slovensku a slubuje, že prispeje svojou troškou k Rochowanského knihe o Bulharsku. ZPH 347, kartón číslo 7, spis Columbus in der Slowakei, Zuschriften zum Buch. 
266 Kolumbus na Slovensku pripravoval znova so súhlasom a s finančnou podporou československého Ministerstva zahraničných vecí študijnú cestu na Podkarpatskú Rus, ktorej chcel venovat' d'alšieho sprievodcu. ${ }^{6}$ Odkazujúc na úspech svojho Kolumbusa predkladá vydavatel'stvu Komenský v Bratislave koncept pät'stostranového turistického cestopisu po Československu pod názvom Von Prag bis Jasiňa. Reisetage in der Čechoslovakei (Z Prahy do Jasine. Na cestách po Československu). ${ }^{7}$

Okrem týchto publikácií, ponášajúcich sa svojím konceptom na opus venovaný Slovensku, pripravoval Rochowanski aj edíciu umeleckých bedekrov po jednotlivých mestách pod názvom „Mesto v obraze“ alebo „Obrazy miest“, pričom prvý zväzok mal byt' venovaný Viedni. ${ }^{8} \mathrm{Z}$ týchto plánov sa nepodarilo zrealizovat' nič. K cestopisnému žánru sa Rochowanski vrátil až po vojne vo svojich rakúskych bedekroch Unser Land mit unsern Augen (Naša krajina našimi očami, 1949) a Einladung in die Wachau (Pozvánka do Wachau, 1956).

V súlade s odklínajúcim diskurzom je aj základné koloniálne či „postkoloniálne“ objavitel'ské gesto, ktoré dielo demonštruje nielen svojím názvom, ale aj grafickým stvárnením väzby. Cestovatel' pozoruje z kormy svojej lode panorámu mesta nového kontinentu, ide príznačne o hlavné mesto krajiny. Lod' sa pritom nevolá Santa Maria, ale nesie meno samotného autora. A tak Rochowanski osobne vystupuje v úlohe Kolumbusa, objavujúceho nový kontinent. Konceptuálnej metafore „cesta ako objavovanie kontinentu“, predstavujúcej základnú metaforu tohto diela, sa podriad'ujú aj d'alšie metafory, ktorými Rochowanski charakterizuje neznáme Slovensko. „Slovensko je čarovná stará sedliacka truhlica, naplnená cennost'ami, povest'ami a piesňami, tancujúcou veselost'ou a plačúcimi strašidlami, obrazmi a kvetmi, drevorezbou a stužkami, naplnená životom a žial'om storoči" (Rochowanski 1936: 10). ${ }^{9}$ Metafora sedliackej truhlice zodpovedá nielen významu objavovania ako nachádzania skrytého, v tomto prípade skrytých pokladov, ale naznačuje aj Rochowanského záujem o ludovú kultúru a jeho optiku folklorizácie, ktorou vníma Slovensko - s výnimkou Bratislavy.

Rochowanski síce zdôrazňuje význam cudzineckého ruchu, no jeho dielo rozhodne nechce byt' praktickou turistickou príručkou. Je v prvom rade etnograficko-literárnym cestopisom, v ktorom sú objektívne informácie votkané do subjektívnych zážitkov a postrehov. Folklorizácia ako typ exotizácie Slovenska, respektíve jeho „domorodej“ kultúry, sa prejavuje nielen obsahovým zameraním knihy na ludové umenie a tradičné remeslá, ale aj jej grafickým dizajnom, bohato využivajúcim typické regionálne materiály na väzbu knihy (oravský lan) a ludové ornamenty, napríklad na čierno-bielej a čierno-červenej záložke zdobenej čičmianskym vzorom. Text je bohato ilustrovaný reprodukovanými fotografiami Karla Plicku, Josefa Vydru, Josefa Hofera či Ireny Blühovej. S Plickom a Vydrom

6 L. W. Rochowanskiv liste z 27.júna 1937.ZPH 347, kartón číslo 7, spis Reisebücher über Wien, Polen und die Tschechoslowakei. V tom istom spise tiež list Vyslanectva Československej republiky vo Viedni z 25. júna 1937, ktorý uvádza finančnú podporu Rochowanského cesty na Podkarpatskú Rus vo výške 5000 Kč. 7 5. septembra 1937. ZPH 347, kartón číslo 7, spis Reisebücher über Wien, Polen und die Tschechoslowakei.

8 Dokument nedatovaný. ZPH 347, kartón číslo 7, spis Reisebücher über Wien, Polen und die Tschechoslowakei.

9 Všetky pôvodné citáty z nemeckého originálu v tomto článku preložil J. T. 
sa Rochowanski poznal osobne pravdepodobne od začiatku tridsiatych rokov ${ }^{10}$ a konzultoval s nimi svoju cestu po Slovensku i výber fotografického materiálu a ukážky ludových piesní. ${ }^{11}$ Toto bibliofilské dielo nie je len knihou o Slovensku, ale vd'aka materiálovému prevedeniu je aj kúskom tejto krajiny ako takej. Text a jeho referent tvoria spoločný celok.

\section{Poetika flanéra a geografia zmyslov}

Vstupnou bránou na Slovensko je pre cestovatela tradične jeho hlavné mesto. Rozprávač Rochowanského cestopisu však neprichádza do Bratislavy na lodi ako Kolumbus, ale limuzínou Praga a s vlastným šoférom. Bratislava je východiskovým bodom jeho objavitel'skej expedície a spolu s opisom jej okolia smerom k Malým Karpatom a na Záhorie tvorí tretinu celej publikácie. Rozprávač vystupuje v dvoch striedajúcich sa polohách: ako flanér, unášaný mestom a spájajúci blúdenie s údivom (wandering/wondering; Amin-Thrift 2002: 14), a ako ciceron, vysvetlujúci historicko-politické a kultúrne súvislosti nielen čitatel'ovi, ale aj svojmu známemu, zahraničnému profesorovi s prezývkou ,fesorko“, s ktorým sa celkom náhodou - ved' ako inak v prípade flanéra - stretáva v Bratislave a berie si ho za spoločníka na prechádzkach po meste.

Flanérskym gestom začína aj opis Bratislavy, tvoriaci začiatok celého diela:

„Od môjho príchodu do Bratislavy uplynulo len pár hodín. Zacítil som mäkkost'vzduchu, zachytil zvuk hodín, sledoval, ako hlasy na ulici klesajú a stúpajú, šiel v ústrety všetkým liudom, akoby prichádzali len ku mne a ponúkali mi svoju tvár, pach neznámeho ma viedol a zvádzal námestiami a uličkami bez toho, aby som niečo z tých mnohých výjavov chcel rozoznat', určit' ći zaradit', bez časového harmonogramu a plánu, ako sa zmocnit'mesta, bez usporiadaných zámerov, iba so želanim, otvorit' svoje pocity vnemom" (Rochowanski 1936: 13).

Prvé vety knihy sú jej poetickým programom. Načrtávajú spôsob, akým bude cestovatel'pristupovat'k svetu okolo seba a akým ho následne bude sprostredkovávat' svojim čitatel'om. Základnými prvkami jeho poetiky, percepcie i písania sú pohyb, spontánnost', fragmentárnost'a dôraz na zmyslové vnímanie. Bliži sa tak chápaniu Michela Serresa, definujúceho flanéra, respektíve pútnika ako postavu akumulujúcu a miešajúcu vo svojom tele pasáže, krajiny, zvyky a jazyky (Serres 2008: 258). Rovnako ako flanér kombinujúci pozorovanie a spoznávanie mestských rituálov so zmyslovou dimenziou mestského života (Middleton 2019: 957), aj Rochowanski vytvára obraz o meste prostredníctvom senzorických vnemov.

10 K. Prešnajderová predpokladá v citovanom článku, že Rochowanski nadviazal kontakty s bratislavskou Školou umeleckých remesiel, ktorej bol Vydra riaditel'om, v roku 1932 (Prešnajderová 2019: 41). Rochowanského bratislavské kontakty vo všeobecnosti siahajú už do dvadsiatych rokov. V dobovej tlači sú doložené jeho prednášky na pozvanie Obchodnej a priemyselnej komory o zariadení a výzdobe moderného bytu 14. februára 1927 (N. N. 1927b) a o moderných ludových obytných stavbách vo Viedni 15. decembra 1927 (N. N. 1927a). Zachovaná korešpondencia s Plickom dokumentuje vzájomné kontakty v roku 1931, ked' Rochowanski organizuje vo Viedni premietanie Plickových dokumentárnych filmov Po horách, po dolách (1929) a Jaro na Podkarpatské Rusi (1928). Plickov list Rochowanskému z 5. marca 1931. ZPH 347, kartón číslo 3, spis Plicka, Karol.

11 Pozri ZPH 347, kartón číslo 3, spisy Plicka, Karol a Vydra, Frida und Josef. 
268 V duchu koncepcie geografií zmyslov (Rodaway 1994) dáva zmysel (senzorický vnem) konkrétnemu miestu jeho zmysel (význam). ${ }^{12}$

Pevnou súčast'ou Rochowanského obrazu Bratislavy sú preto chut' a zvuk, ktoré nachádza v reštauráciách, v kaviarňach a vo viechach. Prv než vezme rozprávač profesora na prechádzku mestom, dá mu v kaviarni okúsit' bratislavské makové a orechové bajgle ${ }^{13}$ so slovami: „mesto, krajinu, treba najprv vnímat' a naučit sa chápat chutovými nervami a týmto spôsobom sa cez kuchynský sporák a podnebie v ústach prepracovat'k základným estetickým a umeleckým vlastnostiam" (Rochowanski 1936: 15). Pri sluchových vnemoch si zas rozprávač všíma piesne, ktorými sa kochá neskôr najmä na vidieku, komentuje zvuk jazykov - slovenčiny a mad'arčiny (v prospech slovenčiny) či nemeckých dialektov na Spiši.

Zvuk Rochowanskému dokonca slúži na vytvorenie centrálnej metafory pre spoznávanie, respektíve vnímanie mesta. Nachádzame ju v odporúčaní rozprávača adresovanému akciechtivému profesorovi, ako sa osamelou prechádzkou priblížit mestu: „Slová popretŕhajú tkanivo prvých pohl'adov. Vydajte sa sám na cestu k domom a l'ud'om, spriatelte sa snimi, nalad'te sa na vlastný tón mesta, pekne opatrne, nepýtajte sa na žiadne mená a čisla, pomaly a vnímavo sa hmatajúc predierajte vpred" (Rochowanski 1936: 15; zvýraznil J. T.).

Hoci označenie vlastný tón nie je analytickým pojmom, pripomína také často fenomenologicky podložené estetické koncepty ako genius loci (Norberg-Schulz 2010), atmosféra (Böhme 1995) alebo známy Benjaminov pojem aura, vyznačujúce sa istou významovou difúznost'ou, vágnost'ou, a preto aj pružnostou, respektíve - ako hovorí Andreas Rauh - „pudingovitost'ou“"14 (Rauh 2012: 87). S vlastným tónom mesta môžeme takisto asociovat' sociologický pojem vlastná logika mesta, pod ktorým Helmuth Barking chápe „skryté štruktúry miest ako na danom mieste zabehané, zväčša mlčky pôsobiace procesy vytvárania zmyslu“ (Berking 2008: 19). Všetky tieto koncepty spája úmysel vlastný aj Rochowanského cestopisu a vo všeobecnosti cestopisnému žánru ako takému: uchopit jedinečnost' a autenticitu daného miesta a mesta a odlišsit ho od iných miest. Niet preto divu, že v cestopisných textoch nachádzame literárne náprotivky k estetickým a filozofickým pojmom.

Nemenej dôležité sú však aj vizuálne vnemy, ktoré rozprávač opisuje verbálne a kniha ich sprostredkuje pomocou už spomenutého bohatého obrazového materiálu, pozostávajúceho z niekol'ko sto vysoko kvalitných fotografických reprodukcií architektúry, umeleckých diel, úžitkového umenia, historických dokumentov, prírody a ludí, ako aj z drobných figurálnych kresieb, mapiek, ornamentov či notových záznamov roztrúsených po celej knihe. ${ }^{15}$ Dojem celistvosti pohladu, ktorý takéto vizuálne spracovanie vyvoláva, je, samozrejme, zdanlivý, vyvažuje však fragmentárnost' textu, ktorý neašpiruje na totálny, encyklopedický pohlad.

12 Na dvojaký význam slova ,zmysel“ poukazuje Neal Alexander (Alexander 2017: 39).

13 Typické miestne sladké rožky, ktoré sa pod názvom Pressburger Mohn- und Nussbeugel predávali a na niektorých miestach sa predávajú dodnes aj vo Viedni.

14 Rauh odvádza atribút „pudingovitý“ $z$ výroku Friedricha Engelsa: „The proof of the pudding is in the eating", nazerajúceho na relevantnost' teórie nie z jej pojmovej jednoznačnosti, ale využitel'nosti v praxi (Rauh 2012: 11 a nasledujúce).

15 Autorom perokresieb a kresieb tušom bol Jaromír Jindra (1895 - 1984). Množstvo fotografií získal Rochowanski od Krajinského úradu, Cudzineckého zväzu v Bratislave a Vedeckých ústavov mesta Bratislavy. 
Od samého začiatku svojho cestopisu predvádza Rochowanski spontánnost' a zážitkovost', a tak čitatel'a neprekvapí, ked' mu rozprávač prináša informácie skôr prostredníctvom príbehov než faktografického rozprávania. Tento štýl aj explicitne tematizuje. Napríklad miesto archeologicko-historického diskurzu k bratislavskému hradu od rímskeho a keltského opevnenia až po romanticky spustnutú ruinu, na aký sme z cestopisov zvyknutí, uvádza takto:

„Bolo by potrebnénapisat'biografiu hradu, nie pomocou mŕtvych čisel a mien či nekonečných výpočtov. Mala by sa vykreslit' dramaticky živo: výmena obyvatel'ov v plnej zbroji a plnom šate storočí, ich prichod a odchod, ich deložovanie a umieranie, ako z okien kriči strach a očakávanie, kliatba a vitazstvo, ako na vežiach vejú rôzne zástavy násilia, ako sa plytvanie strieda s biedou, dýka sitarou, až kým napokon nevyšl'ahne plameň a neohlodá mäso trpiacej budovy až na kost" (Rochowanski 1936:38).

Túto biografiu samotný Rochowanski neponúka, no v duchu flanérskej poetiky skladá svoj text z drobných anekdot, lyricky ladených opisov, kultúrno-filozofických esejistických vsuviek a podobne. Napríklad povinnú etymologickú „jazdu“, ktorú každý sprievodca venuje názvu mesta, rozprávač nahrádza profesorovou historkou o jeho ceste do Bratislavy, pripomínajúcou samotného Kolumbusa, ktorý mieril do Indie a dorazil do Ameriky:

„Len si predstavte, vo viedenskej dopravnej kancelárii som si vypýtal listok do Prešporka, nepozrel som si ho a vybral sa na stanicu. Počas jazdy som si asi trochu zdriemol, potom prišiel sprievodca a naznačil mi, aby som vystúpil. Ked'už som stál pred stanicou, napadlo mi, že sa radšej spýtam, kde som, a tu mi istý muž namrzene odvetil:,v Bratislave“ a so zvláštnym úsmevom odkráčal preč" (Rochowanski 1936:14).

Konomastickému úvodu neskôr na inom mieste rozprávač pridáva s náležitou dávkou irónie výklad latinského názvu mesta:

„Jedna jediná samohláska je príčinou sporu. Jeden vraví, že mesto sa volalo Posonium, druhý tvrdí, že Pisonium. Vtom sa už hlásia odporcovia Pis, spustia tažkú učenú kanonádu a kričia: Pos. Bojovníkov pribúda, mestské pečate, letopočty, názvy miest a osôb, časti stavby, nadávky ako,vokálová korupcia' poletujú sem a tam. Nazdávam sa [...], že boj Pisanov s Posanmi ešte stále nie je definitívne rozhodnuty" “ (Rochowanski 1936: 24).

Komický efekt opisu vyplýva zo zmiešania latiny s nemčinou a vysokého s nízkym, ked'že slabika „Pis“ môže v nemčine akusticky znamenat' imperatív „moč!“ (piss!) a slabika „Pos“ je zas homonymum genitívu slova „zadok“ (nominatív: der Po; genitív: des Pos).

Úvodný opis Bratislavy je typický pre obraz mesta nielen svojím štýlom, ale aj lokalitou. Krátka prechádzka mestom vedie príznačne do kaviarne, konkrétne kaviarne Savoy. Príznačne hned'z viacerých dôvodov. 1. Kaviareň demonštruje príslušnost' mesta a krajiny k stredoeurópskej kultúre, ktorej konzumenti sú zároveň adresátmi diela. Kolumbovská expedícia do neznáma, ktorá má do 
270 krajiny prilákat' d'alších „prieskumníkov“, sa tak nezačína šokom, ale postupným prechodom od známeho k neznámemu, čo zodpovedá turistickému konceptu semiexotiky. 2. Kaviarne, reštaurácie a viechy patrili vzhl'adom na dôležitost' potravinárstva v Bratislave (vinárstvo, liehovarníctvo, cukrovinkárstvo, konzervárenstvo či mäsospracujúci priemysel) k nosným štruktúram regionálnej ekonomiky, ktoré majú vplyv aj na charakter mesta (Suttles 1984; Schiffauer 1997). 3. Kaviareň je typickým interiérom flanéra, ktorý v ňom môže naplno rozvinút svoje zmyslové vnímanie sveta.

V kaviarni sa cestovatel'stretáva aj so spomínaným profesorom a odtial'to spolu vyrážajú na odporúčanie priatela Bébého, za ktorým sa skrýva v cestopise nemenovaný pracovník Mestského múzea Bohuslav Bezděk, ${ }^{16}$ rovno na Vysokú, pod viechu. Viecha predstavuje architektonický a sociokultúrny medzistupeň medzi urbánnym interiérom kaviarne a exteriérom mesta a tiež medzi mestskou a rurálnou formou družnosti. Rozprávač ju využíva na vykreslenie d'alšieho dôležitého prvku lokálneho koloritu-viacjazyčnosti ako symbolu mierumilovného porozumenia medzi národmi:

„zrazu sme si všimli, že každý stôl bol samostatný jazykový ostrov, z každej piesne týchto stolov viala neviditelne iná národná zástava, no všetky farby sa mierumilovne a žiarivo trepotali pod hviezdnou klenbou dvora a zdalo sa nám, že sme sa dostali do novej Spoločnosti národov" (Rochowanski 1936:17).

\section{Uprostred trópov - koordináty intertextuality}

Čítanie mesta sa u Rochowanského prelína s čítaním kníh. K použitiu postmodernej metafory čítania ako orientácie v priestore, a tým pádom aj k vytvoreniu analógie medzi mestom a textom dáva oprávnenie samotný Rochowanski, ked' píše: „Je to úžasná radost'obist' a prečitat' tol'ko neznámych ulíc a uličiek" (Rochowanski 1936: 68). Túto analógiu medzi putovaním/pohybom a literatúrou by sme mohli doplnit' o d'alšiu. S tečúcim vínom vo vieche sa dáva do pohybu aj čas smerom do druhohôr a naši cestovatelia sa v akomsi nočnom delíriu stávajú svedkami vrásnenia Karpát a prudkého rastu vegetácie. „Sme uprostred trópov, nádhera!“ (Rochowanski 1936: 22), zvolá profesor, ktorý medzičasom stratil rovnováhu, netušiac, že v sprievode rozprávača, dešifrujúceho mestský text, jeho metafory, synekdochy, metonymie a irónie, sa uprostred trópov nachádza neustále.

Texty o meste sú vždy aj textami o textoch. Aj Rochowanského rozprávač sa pri opise Bratislavy opiera o lektúru pomerne bohatej topografickej literatúry. Spolu so svojím spoločníkom nielen blúdia mestom, užívajúc si ho spolu s vínom plnými dúškami, ale aj intenzívne čítajú a lektúru komentujú. A tak sa k slovu dostávajú, či už menovite alebo anonymne, doboví uhorskí a rakúski osvietenci - zakladatel'uhorskej štatistiky Martin Schwartner, geograf Johann Matthias Korabinsky (priatel'Bébé ho ochotne zapožičal z fondov Mestského múzea), ${ }^{17}$ diva-

16 B. Bezděk (1880 - 1955), kunsthistorik a etnograf, od roku 1936 pracovník Múzea mesta Bratislavy (Hupko 2018: 76, 121 a 123).

17 B. Bezděk v korešpondenčnom lístku L. W. Rochowanskému z 9. februára 1939. ZPH 347, kartón číslo 1, spis Bezděk, Bohuslaw. 
delník a autor cestopisov Johann Friedel či botanik Stephan Lumnitzer. Zaznie aj Herderov prorocký hlas:

„Ked'že sa to ani nedá predstavit'si ináč, než že zákonodarstvo a politika v Európe musia a budú miesto bojovného ducha čoraz viac podporovat'míkvu usilovnost'a pokojné spolunaživanie medzi národmi, tak sa aj vy, hlboko zapadnuté, kedysi usilovné a štastné národy, raz konečne prebudíte z vášho dlhého úmorného sna, oslobodite z otrockých okov, budete využivat'Vaše krásne krajiny od Jadranského mora až po karpatské vrchy, od Donu až po Vltavu ako svoj majetok a na nich budete smiet'slávit' Vaše staré sviatky pokojnej usilovnosti a práce" (Rochowanski 1936: 40).

Vol'ba tohto slávneho citátu zo štvrtej hlavy šestnástej knihy Herderových Ideí k filozofii dejín l'udstva - takzvaná kapitola o Slovanoch (Herder 1989: 698) - isto nebola náhodná. Upínali sa k nemu generácie úfajúcich aj zúfajúcich slovanofilov (Kollár 1837: 67; Kollár 1839: 157; Drews 1990: 156-170), a to nielen slovenských a českých (Ziegengeist 1978). V nových politických pomeroch Československej republiky zas veštba spol'ahlivo fungovala aj ako tribút československej štátnej ideológii. Nuž a aby nebola iba ovca celá, ale aj vlk sýty, tak sa popri slovanstve, a teda Československej republike, vzdáva reverencia historikovi praveku Oswaldovi Menghinovi, neskoršiemu rakúskemu ministrovi školstva v takzvanom anšlusovom kabinete v marci 1938. Pravda, je otázne, do akej miery Rochowanski poznal okrem Menghinových odborných kunsthistorických názorov na abstraktné umenie na východe od rieky Moravy, ktoré cituje (Rochowanski 1936: 92), aj jeho antisemitské a fašistické postoje (Taschwer 2016: 230). Navyše v časoch, ked' vyšiel Kolumbus na Slovensku, sa mnohým zdalo, že predstavy o celej ovci a sýtom vlku sa navzájom nevylučujú.

\section{Súčasnost' nesúčasného}

Základným konceptom Rochowanského ponímania dejín mesta je súčasnost' nesúčasného, ktorú pozoruje po celej krajine: „To prekvapujúce, oživujúce a takmer neuveritel'né je, že človek v tejto krajine prechádza najrozličnejšimi vrstvami ludstva. Tie sa však nenachádzajú jedna pod druhou, ale vedl'a seba, mnohéstoročia prebývajú vedl'a seba, dvere vedl'a dverí, ich tvár zostala nezmenená" (Rochowanski 1936:254).

V Bratislave si ju všíma najmä na koexistencii jej stredovekej a celkom modernej architektúry vilových štvrtí, ktorú vysoko vyzdvihuje: „Kde sa človek prejde ulicami a vilovými štvrtami Bratislavy, ziska pri pohl'ade na novopostavené budovy obraz odhodlania a istoty, takmer nikde sa nenájde kompromis či návrat k predošlému štýlu prežúvavcov" (Rochowanski 1936: 90). Zo zvedavosti sa rozprávač pristaví pri jednej z víl a požiada obyvatel'ov, či by smel vidiet' interiér. Nasleduje jedna z mnohých inscenovaných náhod, ktorá mu umožňuje propagovat' svoj vlastný umelecký vkus a blízkost' Bratislavy a Viedne:

„Sotva som vošiel do haly, zvolal som prekvapene a s radost'ou: Hoffmann, Josef Hoffmann! Celé vnútorné zariadenie pochádzalo od neho. Vtedy som si uvedomil, že vzt'ahy k viedenskému stavitel'stvu, vel'kému zdroju moderny, sa neprerušili, že vel'ká sila pravého umenia vyžaruje všetkými smermi, v každej dobe, nehl'adiac na 
272 hranice, že tieto dary sa v každej dobe prijímajú s radost'ou. Tvorivým l'ud'om patrí celá zem" (Rochowanski 1936: 91-92).

Svoje nadšenie pre Josefa Hoffmanna Rochowanski neskôr pretavil aj do samostatnej publikácie venovanej tomuto priekopníkovi modernej architektúry a spoluzakladatel'ovi Wiener Werkstätte (Rochowanski 1950).

$S$ víziou modernej funkcionalistickej architektúry výrazne kontrastuje ani nie tak gotická, renesančná či baroková Bratislava ako rozprávačov „živý“ obraz stredovekého geta, ktoré si predstavuje prechádzajúc sa po Zámockých schodoch: Židia v červených kabátoch so žltým flakom a špicatými klobúkmi (Rochowanski 1936: 41). Prekvapujúci nie je samotný obraz, zodpovedajúci stredovekému odevu predpísanému pre židovské obyvatel'stvo, aby sa hned' na prvý pohlad odlišovalo od krest'anského. To, čo zaráža, je skutočnost', že okrem tohto opisu a legendy o chýbajúcich hodinách na jednej zo štyroch strán Michalskej veže, na ktoré údajne Židia odmietli prispiet', Rochowanski nespomína Židov v Bratislave ani slovkom. So Židmi asociuje iba stredovek. Nepíše o Chatamovi Soferovi ani bratislavskej ješive, nespomína synagógu hned'vedl'a Dómu. Takmer úplné zamlčanie židovského obyvatel'stva a jeho kultúry je však ešte šokujúcejšie pri ceste po východnom Slovensku, pri ktorej padne jediná zmienka o židovskom gete v Huncovciach (Rochowanski 1936:383).

Ignorovanie a či tabuizovanie židovského etnika je príkladom mechanizmu sémantického zatvorenia. Ked'že Rochowanski vo svojom diele neprejavuje sympatie voči fašistickej ideológii, nazdávam sa, že opomenutie Židov a ich kultúry na Slovensku vyplývalo z Rochowanského vydavatel'ského kalkulu. Ked'že dielo bolo adresované po nemecky čítajúcemu publiku, autor si nemohol dovolit' nezobrat' na vedomie očakávania nemeckých a rakúskych čitatel'ov, ktoré boli v roku vydania cestopisu výrazne determinované aktuálnou národnosocialistickou a austrofašistickou kultúrnou politikou. Rochowanski dokonca plánoval pre svoju knihu organizovat' za pomoci lipského vydavatel'a Aretza reklamnú kampaň priamo v Nemeckej ríši. ${ }^{18}$

Kniha v žiadnom prípade nesympatizovala s fašizmom. Bola, naopak, hlásnou trúbou československej štátnej ideológie s primeraným, nie však prehnaným ocenením domácej nemeckej kultúry na Slovensku. Zjavne však nechcela dráždit' potenciálnych kupcov a návštevníkov Slovenska. Mimochodom, Rochowanského podnikatel'ský duch bol zjavne silnejší než jeho politický inštinkt. Ked'že nákladné výpravné vydanie cestopisu sa skončilo ekonomickým neúspechom, pretože vydavatel'stvo Eosverlag išlo po vydaní knihy do konkurzu, Rochowanski neváhal iniciovat' nové vydanie knihy hned' po vyhlásení samostatnej Slovenskej republiky v marci 1939, samozrejme, so zvážením príslušnej politicko-historickej aktualizácie. ${ }^{19} \mathrm{~S}$ rovnakým nápadom píše v roku $1955 \mathrm{~J}$. Vydrovi

18 L. W. Rochowanski v liste vydavatel'stvu Eosverlag z 8. februára 1935. ZPH 347, kartón 4, spis Eos-Verlagsanstalt.

19 L. W. Rochowanski v listoch bratislavskému vydavatel'stvu Eosverlag z 24. marca a zo 7. apríla 1939. ZPH 347, kartón číslo 4, spis Eos-Verlagsanstalt. 
do komunistického Československa. ${ }^{20}$ Ani jeden nápad sa neujal. Bolo by zaují- 273 mavé vidiet', čo všetko by bol Rochowanski nútený/ochotný zamlčat', ak by jeho Kolumbus vyšiel v reedícii.

\section{Záver: otvorený a zatvorený mestský text}

Ak sa vrátim k otázkam formulovaným v úvode štúdie, z akých prvkov skladá Rochowanski obraz Bratislavy a akým štýlom sa vyznačuje jeho rozprávanie, možno na záver povedat', že tak jednotlivé obsahové elementy, ako aj spôsob rozprávania vyplývajú z optiky flanéra. Prechádzky mestom sú kombinované so zastávkami $\mathrm{v}$ kaviarňach, vo viechach a v reštauráciách. Z jednotlivých zmyslových vnemov autor komponuje multisenzorický obraz mesta, hladajúc jedinečný charakter mesta, jeho vlastný tón, ku ktorému patrí chut' makových rožkov a vína rovnako ako viacjazyčný spev vo vieche. Mesto sa hned' od počiatku ponáša na Viedeň, nielen svojou kulinárskou kultúrou, ale aj afinitou k modernej architektúre a dizajnu. Tak ako je flanér v chápaní $M$. Serresa krížencom, mulatom, miešancom (Serres 2008: 258), aj svet, ktorý okolo seba v Bratislave vníma, je pestrou zmesou, koexistenciou nesúčasných svetov. Týmto vnímaním prispieva Rochowanski $\mathrm{k}$ sémantickému otvoreniu bratislavského mestského textu. $\mathrm{V}$ dobovom politickom kontexte však zároveň niektoré jeho významové vrstvy zahladzuje, ako som ukázal na príklade obrazu Židov.

V kontexte celej knihy má kapitola o Bratislave nielen úvodnú a rámcovú funkciu (po ceste po Slovensku sa rozprávač opät' vracia do hlavného mesta), ale tvorí aj kontrast k zvyšku krajiny. Pulz modernosti, ktorý cítit pri jej obraze, nie je pre ostatnú čast' krajiny ani pre knihu ako celok určujúci. Rochowanski sa omnoho viac koncentruje na ludovú kultúru a prepojenie obyvatel'stva na ludové tradície, ktoré vníma ako ešte stále živé a autentické. So skutočnost'ou, že Slovensko malo v medzivojnovom období väčšmi rurálny než urbánny charakter, sa nedá v zásade nesúhlasit'. Silná koncentrácia na folklór, atraktívny pre turistov rovnako ako pre etnológov, však zároveň zahladzuje stopy prebúdzajúcej sa modernity. Táto výhrada zaznieva aj z niektorých inak pochvalných dobových recenzií. ${ }^{21}$

Rochowanského cestopis osciluje vo vnímaní Slovenska medzi modernou a tradíciou, medzi československou demokraciou a čiastočne tolerovaným austrofašizmom, medzi moderným umeleckým dielom a predstavou finančného zisku. Bratislavské vydavatel'stvo Eos, ktoré knihu vydalo, skrachovalo a knižný projekt sa skončil finančným fiaskom. Politický vývoj v Európe zničil na desatročia kultúrne vzt'ahy medzi Rakúskom a Československom, o ktoré sa Rochowanski usiloval. To, čo zostalo, je dokument kultúrneho kontrastu - pastorálnej idyly

20 Vliste zo 17. januára 1955 píše J. Vydra L. W. Rochowanskému, že jeho Kolumbus bol znova objavený, má vel'a čitatel'ov a dostáva sa mu uznania. L. W. Rochowanski reaguje na list 4. februára 1955 nápadom, či by nebolo možné preložit' knihu do češtiny a primerane upravit', ked'že niektoré pasáže už nie sú aktuálne. J. Vydra sa následne obracia na vydavatel'stvo Artia, no vydavatel' neprejavuje záujem, ked'že kniha vraj už vyšla v jednom zo svetových jazykov (list zo 16. septembra 1955). Pozri ZPH 347, kartón číslo 3, spis Korrespondenzen mit Einzelpersonen. Vydra, Frida und Josef.

21 Istý recenzent Rochowanskému pri všetkom uznaní vyčíta (do istej miery právom) nevyvážený výber reprodukcií súčasného výtvarného umenia, v ktorom sú moderní slovenskí maliari zastúpení nedostatočne (N. N. 1936). 
274 a urbánnej modernosti, ktorý Rochowanski zachytil nielen pohl'adom spisovatel'a, ale aj pohladom antropológa.

Čítanie mesta sa u Rochowanského mieša s čítaním textov a spolu tak vytvárajú mestský text, v ktorom sa z pohladu percepcie reálne existujúce mesto nedá oddelit' od jeho literárnych reprezentácií. Tieto sa napokon vo svojej materiálnej podobe stávajú súčastou takzvaného materiálneho palimpsestu, uchovávaného v knižniciach. Vo svojej mentálnej podobe zas prispievajú k urbánnej imaginácii, to jest k mestu ako nemateriálnemu palimpsestu. ${ }^{22}$ Slovami sociológa Rolfa Lindnera, prenesenými na tento prípad, možno povedat', že Bratislava „vytvára ako kultúrne kódovaný priestor, preniknutý históriou a historkami, imaginárny priestor, prekrývajúci ten fyzikálny do tej miery, do akej ho prežívame a vnímame prostredníctvom obrazov a textov“ (Lindner 2008: 86). Týmto spôsobom dochádza k sémantickému otvoreniu mesta a multiplikácii mestských lektúr, tvoriacich podla Rolanda Barthesa jazyk mesta: „Bude nás musiet' byt' mnoho, aby sme dešifrovali mesto, v ktorom sa nachádzame“ (Barthes 1988: 208). Dešifrujúc Rochowanského, stávame sa jednými z nich.

Štúdia je výstupom grantového projektu APVV 17-0254 Jazykové a komunikačné problémy na Slovensku a ich manažment. Zodpovedný riešitel': prof. PhDr. István Lanstyák, CSc. Doba riešenia: 2018 - 2022 .

\section{Archívne pramene}

Wienbibliothek im Rathaus, Oddelenie rukopisov, osobný fond Leopolda Wolfganga Rochowanského, ZPH 347.

\section{Pramene}

HERDER, Johann Gottfried, 1989. Ideen zur Philosophie der Geschichte der Menschheit. Werke in zehn Bänden. 6. Bd. Frankfurt am Main: Deutscher Klassiker Verlag [nemecký originál 1784 - 1791]. ISBN 3618607652.

KOLLÁR Ján, 1839. Sláwa bohyně a pưwod gména Slawio čili Slawjanuw. Pest: Trattner.

KOLLÁR, Ján, 1837. Ueber die literarische Wechselseitigkeit zwischen den verschiedenen Stämmen und Mundarten der slawischen Nation. Pest: Trattner.

N. N.,1927a. Der bekannte Wiener Schriftsteller L. W. Rochowansky. Pressburger Zeitung, roč. $164,14.12 .1927$, s. 4.

N. N., 1927b. O zariad'ovaní a výzdobe bytu. Slovenský denník, roč. 10, 18. 2. 1927, s. 2.

N. N., 1935. Columbus in der Slowakei. Der Tag, roč. 14, 29. 12. 1935, s. 4.

N. N., 1936. Vídeň průkopníkem Slovenska. Vídeňské noviny, roč. 3, 6. 2. 1936, s. 5.

P. V., 1935. Kolumbus na Slovensku. Slovenský denník, roč. 18, 23.11. 1935, s. 2.

ROCHOWANSKI, Leopold Wolfgang, 1936. Columbus in der Slovakei. Bratislava: Eosverlag. ROCHOWANSKI, Leopold Wolfgang, 1950. Josef Hoffmann. Eine Studie geschrieben zu seinem 80. Geburtstag. Wien: Staatsdruckerei.

\section{Literatúra}

ALEXANDER, Neal, 2017. Senses of place. In TALLY, Robert T. Jr, ed. The Routledge Handbook of Literature and Space. New York: Routledge, s. 39-49. ISBN 9781138816350.

22 Pozri Wietschorkeho definíciu mesta z pohl'adu kultúrnych reprezentácií mesta: „Mesto sa stáva istým druhom tak materiálneho, ako aj nemateriálneho palimpsestu, do ktorého sa neprestajne vpisujú nové posolstvá“" (Wietschorke 2013: 205). 
BARTHES, Roland, 1988. Semiologie und Stadtplanung. In BARTHES, Roland. Das semiologische Abenteuer. Frankfurt a. M.: Suhrkamp [francúzsky originál 1985], s. 199-209. ISBN 978-3-518-11441-4.

BERKING, Helmut, 2008. „Städte lassen sich an ihrem Gang erkennen wie Menschen“ - Skizzen zur Erforschung der Stadt und der Städte. In BERKING, Helmut - LÖW, Martina, ed. Die Eigenlogik der Städte. Neue Wege für die Stadtforschung. Frankfurt a. M. - New York: Campus, s. 15-32. ISBN 9783593387253.

BÖHME, Gernot, 1995. Atmosphäre. Essays zur neuen Ästhetik. Frankfurt a. M.: Suhrkamp. ISBN 3518119273.

DREWS, Peter, 1990. Herder und die Slaven. Materialien zur Wirkungsgeschichte bis zur Mitte des 19. Jahrhunderts. München: Otto Sagner, ISBN 3876904838.

HUPKO, Daniel, 2018, ed. Vo víre dejín. 150 rokov Múzea mesta Bratislavy. Bratislava: Múzeum mesta Bratislavy. ISBN 978-80-89636-29-7.

LINDNER, Rolf, 2008. Textur, imaginaire, Habitus - Schlüsselbegriffe der kulturanalytischen Stadtforschung. In BERKING, Helmut - LÖW, Martina, ed. Die Eigenlogik der Städte. Neue Wege für die Stadtforschung. Frankfurt a. M. - New York: Campus, s. 83-94. ISBN 9783593387253.

MIDDLETON, Jennie, 2019. Walking City. In HUTCHISON, Ray, ed. Encyklopedia of Urban Studies. Los Angeles: Sage, s. 957-959. ISBN 9781412914321.

NORBERG-SCHULZ, Christian, 2010. Genius loci. Krajina, misto, architektura. Praha: Dokořán [anglický originál 1980]. ISBN 9788073633035.

PREŠNAJDEROVÁ, Klára, 2019. Leopold Wolfgang Rochowanski - rakúsky objavitel' moderného Slovenska. Designum, roč. 21, č. 2, s. 39-43. ISSN 1335-034X.

RAUH, Andreas, 2012. Die besondere Atmosphäre. Ästhetische Feldforschungen. Bielefeld: transcript. ISBN 3837620271.

RODAWAY, Paul, 1994. Sensuous Geographies. Body, Sense and Place. London: Routledge. ISBN 9780415513395.

SCHENK, Frithjof Benjamin, 2007. Die Stadt als Monument ihres Erbauers. Orte der symbolischen Topographie. In SCHLÖGEL, Karl-SCHENK, Frithjof Benjamin - ACKERET, Markus, ed. Sankt Petersburg. Schauplätze einer Stadtgeschichte. Frankfurt a. M.: Campus, s. 47-58. ISBN 9783593383217.

SCHIFFAUER, Werner, 1997. Zur Logik von kulturellen Stromungen in Großstädten. In SCHIFFAUER, Werner, ed. Fremde in der Stadt. Zehn Essays über Kultur und Differenz. Frankfurt a. M.: Suhrkamp, s. 92-127. ISBN 9783518391990.

SERRES, Michel, 2008. The Five Senses: A Philosophy of Mingled Bodies. London: Continuum [francúzsky originál 1985]. ISBN 9781441122209.

SUTTLES, Gerald D., 1984. The Cumulative Texture of Local Urban Culture. American Journal of Sociology, vol. 90, č. 2, s. 283-304. ISSN 1537-5390.

TANCER, Jozef, 2013. Neviditelnémesto. Prešporok/Bratislava v cestopisnej literatúre. Bratislava: Kalligram. ISBN: 9788081016653.

TASCHWER, Klaus, 2016. Geheimsache Bärenhöhle. Wie ein antisemitisches Professorenkartell der Universität Wien nach 1918 jüdische und linke Forscherinnen und Forscher vertrieb. In FRITZ, Regina - ROSSOLIŃSKI-LIEBE, Grzegorz - STAREK, Jana, ed. Alma mater antisemitica. Akademisches Milieu, Juden und Antisemitismus an den Universitäten Europas zwischen 1918 und 1939. Zv. 3. Wien: new academic press, s. 221-242. ISBN 978-3-7003-1922-1.

WIETSCHORKE, Jens, 2013. Anthropologie der Stadt: Konzepte und Perspektiven. In MIEG, Harald A.-HEYL, Christoph, ed. Stadt. Ein interdisziplinäres Handbuch. Stuttgart: Metzler, s. 202-221. ISBN 978-3-476-05189-9.

Doc. Mgr. Jozef Tancer, PhD.

Katedra germanistiky,

ZIEGENGEIST, Gerhard, ed., 1978. Johann Gottfried Herder. Zur Herder-Rezeption in Ost- und Südosteuropa. Berlin: Akademie-Verlag. nederlandistiky a škandinavistiky

Filozofická fakulta

Univerzity Komenského

Gondova 2

81102 Bratislava

Slovenská republika

E-mail: jozef.tancer@uniba.sk 